\title{
Corpo, afeto e educação
}

\author{
Sérgio Oliveira dos Santos ${ }^{1}$ \\ Wesley Adriano Martins Dourado ${ }^{2}$
}

\begin{abstract}
Resumo: A reflexão pretende articular as noções de "corpo próprio", "mundo vivido" e "intencionalidade", tal como as concebe a fenomenologia, em particular Maurice Merleau-Ponty, com a relação entre "educação e querer bem" em Paulo Freire, a motricidade humana, tal como a concebe Manuel Sergio e a compreensão da relação "educação e cuidado" em Adélia Prado. A referida trama não é um fim em si mesma: ela pretende criar o solo para que se pergunte pela possibilidade de uma experiência educativa e uma prática escolar que não ignore o seu "topos" e os corpos e, deste modo se coloque em perspectiva "utópica". De modo específico, este questionamento nos coloca a pensar sobre a formação docente, as condições do seu trabalho, entre outros aspectos. A reflexão, assim anunciada, quer ser um lugar para problematizar os princípios, valores, ideias que sustentam as ações educacionais e fica longe da pressa de se transformar em didática, em solução. Ela quer colaborar para a criação de outro êthos educativo e isto já está em curso na prática de muitos de nós.
\end{abstract}

Palavras Chave: Corpo próprio; educação, afetividade, querer bem, motricidade, Adélia Prado, Paulo Freire.

Abstract: This paper presents reflections on phenomenological concepts, especially as conceived by Merleau-Ponty ("own's body" and others) in connection with Paulo Freire (Education and "querer bem"), the human motricity (Manuel Sergio), and Adélia Prado (Education and "cuidado").

Keywords: Educational experiences, body, motricity, education. Adélia Prado. Paulo Freire.

\section{Introdução}

Sobre a mesa lugares teóricos: a fenomenologia, a pedagogia da autonomia, a motricidade humana e a obra de Adélia Prado. Seria mais apropriado dizer, afinado com Josef Pieper, "teórico" como

(...) o olhar humano quando o ente, o mundo for-lhe algo mais do que o campo, o material, a matéria prima da atividade humana. "Teoricamente", no sentido pleno, poderá olhar na realidade somente aquele para quem o mundo é de algum modo digno de veneração, criação final em sentido estrito. (2007, p. 20)

Assim, estes lugares teóricos são, ao mesmo tempo expressão de uma percepção do mundo, do outro, mas, nos limites desta reflexão, se constituem também

\footnotetext{
${ }^{1}$ Doutorando e Mestre em Educação - UMESP. Prof. de Educação Física e Judô - PMSCS. Coordenador do Núcleo de Formação de Judô de SCSul. Membro fundador da REMoHC - Rede Educativa de Motricidade Humana e Corporeidade. Professor formador CECAPE - SCSul. Bolsista CAPES/PROSUP.

2 Possui graduação em Filosofia pela Universidade Metodista de São Paulo (2000), graduação em Teologia pela Faculdade de Teologia da Igreja Metodista (1997); mestrado em Educação pela Universidade Metodista de São Paulo (2003) e doutorando em educação pela mesma Universidade. Atualmente é professor auxiliar da Universidade Metodista de São Paulo, coordenador do curso de filosofia desta Universidade e professor titular de filosofia da Escola Municipal de Ensino Alcina Dantas Feijão. Tem experiência na área de Filosofia, com ênfase em Filosofia da Educação, atuando principalmente nos seguintes temas: educação, filosofia, fenomenologia e filosofia latino-americana. Tem trabalhos acadêmicos publicados em eventos nacionais e internacionais, revistas e capítulos de livros tratando, em particular, das relações da fenomenologia merleaupontyana com a educação bem como, da relação corpo-conhecimento. Atua, também, em cursos de graduação à distância, em particular no curso de Filosofia, Ciências Sociais, Letras e Pedagogia. É editor responsável pela revista Páginas de Filosofia (https://www.metodista.br/revistas/revistas-ims/index.php/PF)
} 
em lugares possíveis para o nosso próprio exercício teórico. Neste caso, nos valemos destas ideias para exercitar a construção do nosso olhar sobre o mundo, sobre o outro, em especial, sobre a educação. Olhamos o mundo com estas ideias e não por meio delas, que se diga. Admiramos o mundo e dialogamos com as ideias com as quais já convivemos. Seguramente, não queremos ignorar o mundo sobre o qual caminhamos em benefício da preservação caprichosa, talvez teimosa, daquilo que um dia foi experiência de contemplar o mundo. Não queremos o abandono irresponsável das visões do passado. Queremos a trama, o trançar do visto, com as novas, talvez apenas, outras, contemplações. Desejamos aquele exercício de imaginação que costura o já sabido com as novidades do contato com o mundo agora, e possibilita a criação de mundos. Com diz Helen Keller "o trabalhador silencioso é a imaginação que saca a realidade do caos". (KELLER, 2012, p.18)

A perspectiva que se assume diante da educação não decorre de um profundo diagnóstico da realidade escolar, para falar de modo restrito, ou porque tenhamos identificado novas dimensões da educação de modo amplo (o uso da internet, por exemplo), mas por reconhecer que, tratando-se de uma atividade e/ou experiência profundamente humana ${ }^{4}$, ela está sujeita a permanentemente mudar, na medida em que os próprios seres humanos desenham outros modos de ser e habitar.

É bem verdade que as mudanças na educação parecem ir em um ritmo lento ${ }^{5}$, mas é preciso reconhecer que, a despeito das singularidades de cada época, mudanças profundas no modo dos homens e mulheres serem, ao que tudo indica, não acontecem a todo instante.

De qualquer modo, docentes que somos, nos vemos provocados a pensar o lugar do corpo e dos afetos na experiência educativa em sentido amplo, bem como nos limites da prática educativa escolar.

E é aqui que os lugares teóricos anunciados se encontram: todos, a seu modo colocam a afetividade como dimensão da existência dos corpos e, por isto mesmo, próprio da experiência educativa.

Não é incomum que a afetividade seja vista com desconfiança. Dentro da prática escolar ela quase sempre é interpretada como uma postura despolitizada, estratégia de não enfrentamento dos problemas escolares, entre outros.

Por isto fica o convite para acompanhar esta reflexão, pois os lugares que apresentaremos, se não mostram soluções, estratégias que imediatamente podem atingir, alterar a nossa prática, servem para problematizá-la, em benefício de uma educação que não teme se apaixonar.

\section{Olhares sobre a educação.}

O que na sequência se apresentará são dimensões de reflexões filosóficas, filosófico educacionais, poéticas, em particular o que nelas nos ajudam a pensar a educação como espaço de afetividade. Não são todos os pontos de partida que tratam diretamente da educação, e as reflexões que propõem a compreensão implicada de educação e afeto seguem desafiando a nossa criatividade.

\footnotetext{
3 "El trabajador silencioso es la imaginación que saca a la realidad del caos." (p. 18)

${ }^{4}$ Cf. JOSGRILBERG, Rui. Da formação de mundos à imaginação educadora. Notandum 30, set-dez 2012, disponível em: http://hottopos.com/notand30/05-16Rui.pdf. Último acesso: setembro de 2015. Nesta reflexão a criação de mundos é anunciada como o mesmo movimento no qual o ser humano se constrói, posto que não tem um mundo pré-formado. Por isto ele é ser de educação.

${ }^{5}$ Para exemplificar cf. GARCIA, P. S. Inovações e Mudanças: por que elas não acontecem nas escolas? Uma macroanálise envolvendo professores de ciências. 1. ed. São Paulo: LCTE Editora, 2010.
} 
O significado da palavra afeto guarda muita proximidade com a palavra paixão, que em sua origem grega pathos indica a condição daquele que foi afetado. A paixão, ou a experiência de ser afetado indica, inevitavelmente, a condição passiva do apaixonado. Não existe a possibilidade de estabelecer regras para que a paixão aconteça. Nem mesmo se pode prevê-la, ou evitar que se instale, já que se trata de uma condição humana pré-reflexiva. Uma vez afetados temos a possibilidade de conter as provocações do que nos afeta, bem como, aceitar o desafio de seguir na direção do que nos apaixona. Seja qual for a resposta que apresentarmos, a paixão, a afetação já terá provocado em nós deslocamento, aquele "saltar de banda" que coloca a existência em outra perspectiva ou, como diz Pieper, um profundo abalo existencial que nos coloca, novamente, diante de nossa não-conclusividade, o que permite transcender $o$ cotidiano, dar um passo além (2007, p. 12).

É o que nos parece haver nas reflexões que apresentaremos sinteticamente: deslocamentos, desafios para assumir outras perspectivas existenciais, convite ao exercício de nossa criatividade.

\section{Corpo próprio, mundo vivido e intencionalidade.}

Lançar mão da fenomenologia nesta reflexão se justifica pelo esforço teóricometodológico de ver, de olhar a experiência humana numa rede de sentido, o que significa dizer o singular, o ocasional, o episódico se sustenta numa trama de sentidos e significados ${ }^{6}$ que impede que algo seja reduzido a ele mesmo. Dito de outro modo, desde a obra de Edmund Husserl que a fenomenologia se propõe a compreender os fenômenos tal como eles aparecem para o sujeito ${ }^{7}$ ou, como defende Merleau-Ponty, a recolocar as essências na existência ${ }^{8}$, portanto, de uma condição na qual os fenômenos são tomados, apreendidos numa experiência de sentido.

Deste modo corpo próprio, mundo vivido e intencionalidade são noções que tentam descrever momentos da experiência humana de, permanentemente, dar um modo de ser, dar um sentido ao que o cerca e a si mesmo. Trata-se, portanto, da

\footnotetext{
${ }^{6} \mathrm{Na}$ obra de Husserl o sentido e o significado são tomados num entrelaçamento ontológico, ou seja, em inevitável ligação com a existência. Josgrilberg indica que no pensamento de Husserl o sentido, claramente mais amplo que o significado, se refere ao modo de ser das coisas, intuído, recuperado por aquele assombro quando o mundo se apresenta como novidade (2015, p.12). Os significados, por sua vez, são uma tentativa de determinação do sentido, de apreensão deste na linguagem e, por isto mesmo, um recorte, um limite. Cf. LAUAND, Luis Jean, JOSGRILBERG, Rui de Souza. Estudos em Antropologia, Religião e Educação. São Paulo: Factash Editora, 2015.

${ }^{7}$ Urbano Zilles, apresentando os principais elementos do pensamento de Husserl destaca a posição deste filósofo, para quem interessa o fenômeno na sua manifestação à consciência, o que não significa a negação do mundo e da relação que com ele tem o fenômeno, mas que este tem uma dimensão ontológica que não pode ser ignorada. "Segundo ele, o sentido do ser e do fenômeno são inseparáveis". (2002, p.12) Isto indica, portanto, que a tarefa da fenomenologia é estudar “(...) o ser tal como se apresenta no próprio fenômeno" (p.12) ou "(...) estudar a significação das vivências da consciência". (p.12) Em pese que o aparecimento do fenômeno à consciência aponte para um idealismo, é inegável, que ele é dado a uma consciência que está em relação com o mundo e o outro, posto que é sempre consciência de algo. Cf. HUSSERL, Edmund. A crise da humanidade europeia e a filosofia; (intro. e trad. Urbano Zilles). Porto Alegre: EDIPUCRS, 2002.

${ }^{8}$ No prefácio da Fenomenologia da Percepção, Merleau-Ponty apresenta a tarefa da fenomenologia inegavelmente numa implicação com a existência, com o que chama de facticidade, com o mundo, com a experiência, defendendo que a essência que a fenomenologia quer estudar não pode ser encontrada a não ser na existência (1999, p.01). Aqui há plena convergência com a posição de Husserl posto que para este filósofo, segundo Zilles, "as essências são as maneiras características do aparecer dos fenômenos" (2002, p. 14) e, por isto mesmo, a fenomenologia "é ciência de experiência, que descreve os universais que a consciência intui quando se lhe apresentam os fenômenos". (p.14) A facticidade a que se refere MerleauPonty não deve ser entendida como uma redução ao fato, pois a essência aponta para uma experiência de sentido que a ele não se reduz.
} 
afirmação de que o mundo que decorre das nossas vivências, este emaranhado de sentidos e significados, que colorem os rumos do existir no mundo e que, ao mesmo tempo, permanece numa abertura para a construção de novos modos de ser, portanto constitui-se como horizonte ${ }^{9}$, é uma tessitura dos corpos que, abertos ao seu lugar, disponíveis para contemplar o mesmo, para voltar às coisas mesmas - cara afirmação da fenomenologia - é a possibilidade para rever o sentido dado ao mundo, mas ao mesmo tempo, a condição de outras dimensões deste mundo que aparece como possibilidade, como horizonte, se revelarem, se constituírem como novas possibilidades de ser.

Note-se que não falamos de momentos lineares; de um processo desencadeado pelo mundo ou pelo corpo, mas sim, que o viver se apresenta concatenado e sempre aberto a outros arranjos. Seguramente isto aponta para a intencionalidade, noção que pretende indicar que estamos sempre ligados a um mundo ${ }^{10} \mathrm{e}$ que isto não é uma mera construção racional, mas, antes, a própria condição da experiência humana: estamos sempre voltados para um mundo que, por sua vez, é apreendido sempre com um sentido de existir.

Desde estas noções é possível intuir que a afetação corpo-mundo-corpos exige que a experiência educativa não ignore o mundo de sentido presente na "mochila" das nossas crianças; não renuncie que, a despeito da diminuída quantidade de informação sobre o mundo objetivo de crianças e adolescentes, a própria vivência escolar seja antecedida por uma visão de mundo, de ser sem a qual, à semelhança da ciência, queda sem sentido. A educação, desde as ideias aqui indicadas, não poderá criar encaminhamentos, estratégias para ignorar esta experiência de mundo sem que isto represente a redução e/ou descaracterização da sua finalidade. A compreensão do mundo, naquele sentido de unidade que se mencionou anteriormente, é o ponto de partida mesmo de possibilidade da própria educação.

E isto não representa, em absoluto, nenhuma negação da história, da tradição ${ }^{11}$, do que já se sabe sobre o mundo, os belos e complexos conhecimentos da

\footnotetext{
${ }^{9}$ O Lebenswelt, tratado na obra de Husserl, segundo Zilles, pode ser entendido como (...) conjunto estrutural da experiência imediata e fundamento originário do sentido" (2002, p. 16). Portanto, ele é um suporte, mas não uma determinação, da experiência de sentido do corpo. Trata-se de um a priori, um mundo pré-científico ou antepredicativo; como diz Merleau-Ponty “(...) ele é o meio natural e o campo de todos os meus pensamentos e de todas as minhas percepções explícitas (1999, p. 06); é o mundo da experiência, fonte do sentido; é o mundo acolhido em sentido existencial na consciência, no caso do pensamento de Husserl. (2002, p. 32) O mundo vivido, se tem esta dimensão de "fonte", ele se apresenta também como horizonte, ou seja, como uma possibilidade para novos sentidos, para novos modos de ser. Ele é, segundo Zilles, “(...) uma totalidade aberta e viva”. (p. 34) É neste contexto teórico que Josgrilberg defende, tratando do mundo, que "habitamos um mundo comum a todos como horizonte maior e habitamos nossos mundos particulares que se insere no horizonte universal de mundo". (2015, p.15) O mundo da vida é uma referência, portanto, ao solo das vivências humanas, dos sentidos que dela brotam, ressurgem sem que, todavia, o mundo, com o qual estamos ligados, seja algo que me esteja submetido ou plenamente apreendido pela razão. Diz Merleau-Ponty que "o mundo é não aquilo que eu penso, mas aquilo que eu vivo; eu estou aberto ao mundo, comunico-me indubitavelmente com ele, mas não o possuo, ele é inesgotável”. (1999, p. 14) Sobre a noção de horizonte e a sua relação com a educação cf. JOSGRILBERG, Rui. Horizonte hermenêutico e filosofia da educação. Revista do COGEIME. Ano 09; n. 16, junho/2000, disponível em: http://www.cogeime.org.br/revista/cap0816.pdf; último acesso: setembro de 2015.

10 A intencionalidade, segundo Merleau-Ponty pode ser decorrência de nossas decisões, de nossos posicionamentos voluntários, mas, especialmente, é compreendida como uma "unidade natural" do mundo e da vida, o que permite distinguir compreensão de intelecção, posto que a primeira se inscreve nesta experiência de captar o mundo numa unidade da qual não nos apartamos; ela é o "(...) reapoderar-se da intenção total". (1999, p. 16)

${ }^{11}$ Urbano Zilles, nos comentários a obra de Husserl dirá, a respeito da filosofia o que segue: "Segundo Husserl, o discurso filosófico sempre deve manter contato com a intuição. Do contrário redunda em conversa vazia. O retorno à intuição originária é a fonte de verdadeiro conhecimento. Por isso não
} 
ciência, mas, simplesmente, que não é neste lugar que o sentido originário brota. Assim, antes disto tudo, é preciso que a experiência educativa seja capaz de tornar evidente, uma vez mais, o mundo, retirá-lo da opacidade e, como defendeu Pieper, reviver a admiração do mundo, não em busca do extraordinário, mas para ver o mesmo, o simples e se deleitar com a redescoberta e/ou a descoberta de sentidos, de modos de viver. Cabe dizer "redescoberta", pois o atual modo de ser, a maneira como organizamos a experiência de ensinar e aprender foi forjada no suporte de um sentido de mundo e de existir que a ela dava um pulsar mais vigoroso, que permitia, provavelmente, compreendê-la em fácil vinculação com as diferentes dimensões da vida. O retorno defendido pela fenomenologia quer nos colocar novamente diante daquela condição originária, de onde brota o sentido. A apreensão deste sentido poderá dar, ao que agora vivemos novo colorido, mas, pode não ser suficiente para seguir a sustentar e mover o viver. Por isto, fala-se em "descoberta" porque este retorno é, posto que o mundo é horizonte, sempre a possibilidade que o sentido se amplie, se apresente novo, de outros modos. Neste caso, estamos diante da necessidade de reinventar o modo de ser e tudo o que dele decorre. A experiência educativa disto não escaparia.

É Inevitável que aqueles que lidam diariamente com a experiência educativa, especialmente, nos limites da prática escolar, perguntem pelo "como". Seguramente, não estamos apenas diante de um novo posicionamento educacional, mas sobretudo, desafiados existencialmente, a começar do início, do mundo, reinventar o nosso modo de ser em benefício de uma vivência que se redescobre inacabada, de um mundo que permanece misterioso e de saberes que não podem ser apenas úteis, mas antes, entranhados de sentido. Aliás, seria esta a pergunta que, de fato, gostariam de nos fazer as crianças e os adolescentes, quando perguntam pela utilidade dos saberes escolares? Estariam eles solicitando ajuda para ver como tais saberes se ligaram ao existir e/ou se ligam a sua existência?

Não há uma resposta bem acabada para o "como". Todavia, a articulação destas ideias com a educação, na obra de Paulo Freire permitiu intuir, se não um "jeito" de fazer, ao menos um princípio norteador.

\section{O querer bem.}

A obra de Paulo Freire é de uma riqueza ainda por ser devidamente reconhecida em terras brasileiras. Entre os muitos motivos está o fato de ser um esforço de compreensão da experiência educativa num contexto de sentido para os envolvidos nela, o que se liga à inspiração de pensamento do que se tem denominado de filosofia da libertação. Trata-se de indicar que o aprender implica numa vinculação com o viver, com o modo de ser. A experiência de alfabetização deflagrada desde a compreensão deste pensador, parece bem demonstrar isto, pois, onde os métodos tradicionais de alfabetização, focados nas letras, na ligação lógica entre eles falharam, o procedimento que partia do vivido, das palavras e dos sentidos dos que desejavam aprender a ler, não apenas funcionou, com ilustra o que aqui temos indicado.

No livro "A importância do ato de ler", já nos primeiros parágrafos, Paulo Freire bem explicita a inevitável implicação do modo de ser no mundo com a experiência educativa.

convém que a impulsão filosófica parta das filosofias feitas, das opiniões de grandes pensadores, mas das coisas e dos problemas, tendo um ponto de partida imediato". (2002, p. 14) 
A leitura do mundo precede a leitura da palavra, daí que a posterior leitura desta não possa prescindir da continuidade da leitura daquele. Linguagem e realidade se prendem dinamicamente. A compreensão do texto a ser alcançada por sua leitura crítica implica a percepção das relações entre o texto e o contexto. Ao ensaiar escrever sobre a importância do ato de ler, eu me senti levado - e até gostosamente - a "reler" momentos fundamentais de minha prática, guardados na memória, desde as experiências mais remotas de minha infância, de minha adolescência, de minha mocidade, em que a compreensão crítica da importância do ato de ler se veio em mim constituindo.

Ao ir escrevendo este texto, ia "tomando distância" dos diferentes momentos em que o ato de ler se veio dando na minha experiência existencial. Primeiro, a "leitura" do mundo, do pequeno mundo em que me movia; depois, a leitura da palavra que nem sempre, ao longo de minha escolarização, foi a leitura da "palavramundo". (1989, p. 09)

Este entendimento do educador de que a palavra é palavra no mundo, palavra do mundo, palavra para o mundo; que ler remete a um mundo enfeixado de sentidos, aponta para um elemento necessário de uma prática educativa que se pretenda libertadora: o querer bem.

É na obra "Pedagogia da Autonomia" onde encontramos anunciado este saber. Ele figura entre outros tantos que, para Paulo Freire, compõem a experiência educativa libertadora, que renuncia ao determinismo, que reconhece o inacabamento do ser humano, a possibilidade de ser mais e a capacidade transformadora da educação.

O texto se divide em três partes. Na primeira parte a docência é anunciada na inseparável relação com o discente testemunhando, uma vez mais, a visão do pensador de olhar a educação em rede, ou melhor, na imbricação da vida: é a relação docentediscente que permite que, de fato, a docência se realize plenamente. Isto exige que o professor, a professora no seu saber respeite os educandos - diríamos respeite os seus mundos -, transforme o seu saber e fazer uma realidade vivida, corporificada, mantenha-se aberto para o novo, crítico em relação ao instituído, respeitoso da singularidade cultural dos diferentes sujeitos da experiência educativa. Na segunda parte está problematizado o conhecimento. Considerada a condição inacabada do ser humano, o desejo de que a humanidade de cada pessoa se dirija cada vez mais para a libertação, para a autonomia, o conhecimento não pode ser transferência, mas decorrência da curiosidade, da investigação do mundo, da realidade, a fim de dar suporte à esperança, à mudança possível. Na terceira parte o reconhecimento de que a educação é algo próprio dos homens e mulheres: de algum modo os humanos não chegam a ser sem que sejam ensinados a ser. Aqui o compromisso, a liberdade, a escuta, o diálogo, entre outros elementos se constituem como indispensáveis.

E é nesta parte que Paulo Freire indica como saber necessário o querer bem. Lá onde trata da educação como uma necessidade humana dirá que ela não se realizará plenamente sem a afetividade.

E o que dizer, mas sobretudo que esperar de mim, se, como professor, não me acho tomado por este outro saber, o de que preciso estar aberto ao gosto de querer bem, às vezes, à coragem de querer bem aos educandos e à própria prática educativa de que participo. Esta abertura ao querer bem não significa, na verdade, que, porque professor me obrigo a querer bem a todos os alunos de maneira igual. Significa, de fato, que a afetividade não me assusta, que não tenho medo de 
expressá-la. Significa esta abertura ao querer bem a maneira que tenho de autenticamente selar o meu compromisso com os educandos, numa pratica específica do ser humano. Na verdade preciso descartar como falsa a separação radical entre seriedade docente e afetividade. Não é certo, sobretudo do ponto de vista democrático, que serei tão melhor professor quanto mais severo, mais frio, mais distante e "cinzento" me ponha nas minhas relações com os alunos, no trato dos objetos cognoscíveis que devo ensinar. A afetividade não se acha excluída da cognoscibilidade. O que não posso obviamente permitir é que minha afetividade interfira no cumprimento ético de meu dever de professor no exercício de minha autoridade. Não posso condicionar a avaliação do trabalho escolar de um aluno ao maior ou menor bem querer que tenha por ele. A minha abertura ao querer bem significa a minha disponibilidade à alegria de viver. Justa alegria de viver, que, assumida plenamente, não permite que me transforme num ser "adocicado" nem tampouco num ser arestoso e amargo. $(1996,159)$

O educador encerra a sua reflexão apontando para o indispensável cultivo da sensibilidade, da coragem de se deixar abalar com as surpresas, com os desafios das relações humanas. E fazê-lo não é uma estratégia pedagógica ou uma orientação de uma filosofia da educação, mas é a própria condição da experiência educativa e da possibilidade de que os homens e mulheres se constituam. Deixar-se tocar, afetar é um gesto que demonstra o compromisso que temos com os alunos e alunas na tarefa de ajuda-los a serem mais, a se desvencilharem do que impede a vida autônoma, livre.

$\mathrm{O}$ afeto aqui anunciado exige a capacidade de seguir lutando contra o que impede a realização de uma educação libertadora, razão pela qual o docente afetado, que bem quer os seus discentes e a prática educativa, não pode ignorar a luta por melhores condições de trabalho, a necessidade de denunciar os desrespeitos à educação, portanto, não pode esquecer das vinculações políticas do seu compromisso com os educandos.

Note-se que o querer bem é, sobretudo, uma declaração de amor aos seres humanos e ao fazer que visa o bem destes humanos: a prática educativa. Uma educação progressista, tal como a concebeu Paulo Freire, em que pese se inspirar em tantos saberes, se funda e encontra seu sentido de ser no compromisso com os seres humanos e na compreensão da sempre possível reinvenção do mundo e do modo de ser no mundo. De algum modo, arriscamos dizer, todos os outros saberes não serão suficientes para realizar uma experiência educativa que permita o discente ser mais, livre, autônomo se, do início ao fim, a prática educativa não estiver sustentada por esta disposição corajosa de se envolver com os homens e mulheres na sua luta e desejo de ser.

Por isto mesmo, uma prática educativa que bem quer os discentes não os colocará para longe do seu mundo, do seu êthos; não os obrigará a aceitar como suficiente o discurso do útil, do necessário para o trabalho, mas aceitará o risco de procurar o sentido de ser do que se faz em educação. E é aqui que se vai melhor compreendendo a necessidade da curiosidade, da liberdade, do respeito aos saberes dos educandos, da rigorosidade, da alegria, da esperança e de tantos outros saberes: todos eles estão à serviço deste compromisso com a humanidade, tal como ela vive e pode viver nesta comunidade.

Seguramente, nesta obra de Paulo Freire, e em particular no querer bem, encontramos caminhos para enfrentar o "como" que ficou pendente. É preciso fazer anteceder o mundo, o sentido que subjaz aos conhecimentos, seja para melhor 
apreendê-los, seja para reconhecer que não são mais suficientes para a tarefa de nos fazer gente. É preciso desvendar o nosso lugar e, a partir dele, compreender o universo todo.

E o impedimento para isto não está exatamente no currículo, na estrutura escolar, na gestão, mas sobretudo na capacidade de manter vivo o querer bem, o compromisso. E a luta contra o que impede uma educação libertadora é a possibilidade de construir as condições para que o docente siga amando as crianças e os adolescentes, comprometido com a prática educativa.

\section{Motricidade humana: corpos dialógicos e o espaço/tempo compartilhado.}

A motricidade humana é um evento de tempo/espaço compartilhado. Como aponta Manuel Sérgio (2003, p. 29):

A motricidade humana (...) é anterior a própria consciência e sua matriz, dado que ser consciência é ser corpo e, pelo corpo, é movimento, ser-para-os-outros, ser-para-a-transcendência. Ao passar do corpo objeto (o corpo que temos) a corpo-sujeito (o corpo que somos), o corpo impõe-se como complexidade, ou como elemento da complexidade humana (corpo-alma-desejo-natureza-sociedade e assente em dois grandes eixos: o biológico e o relacional (onde a linguagem se integra, evidentemente).

O ser-motrício é o que modela e projeta o tempo/espaço em que se insere. Nessa dimensão, diferentes espaços/tempos são projetados em torno de diferentes intencionalidades. O corpo humanizado se desdobra assim em possibilidades dialógicas intersubjetivas. Esse é o corpo dialógico vivendo o campo relacional, próprio das experiências motrícias, onde não há como deixar de ser afetado pelo outro, ou seja, como relação existência ou si-mesmo chegará ao outro aprofundando a vivência solidária (MERLEAU-PONTY, 2006, p. 38). O ser-motrício é tomado de energia plena de possibilidade relacional, energia efetiva, de afeto e afetação.

Ser-motrício é ser um corpo dialógico, quase como dizer o mesmo por outras palavras. Mas, há vistas para os corpos dialógicos na educação? Do que se ocupa a matemática? Do que se ocupa a língua portuguesa? Do que deve se ocupa a educação física, a história, a geografia, as artes, a ciência?

Temos pra nós que todas deveriam ocupar-se em primeiríssima instância na compreensão dos corpos motrícios dialogantes. Afinal, não é por esse curso que todo o discurso pedagógico percorre?

Entendemos que é na dimensão das ações corporais dialógicas que a educação sensível ao afeto deve se ocupar. É necessário compreender e valorar o si-mesmo afetado pelo outro como modo interdialogante (Ricoeur, 2014, p. 389)

Olhar o humano nos modos relacionais das distintas experiências educativas, analisando o convívio inter-humano e as implicações dessas experiências compartilhadas na formação da identidade, do pertencimento, do reconhecimento e do saber.

A percepção do valor do afeto nas relações corpo-motrícias faz fervilhar um modo de ser cujo valor permite formar sentidos e construir significados para o meuseu existir em um mundo cujo projeto de sentido, criado por seus pares, traz entornos propícios para acolher o saber. Isso, pois que "no movimento humano, há também um 
pré-ato, ou seja, um projeto, uma pulsão, uma intencionalidade, um logos, um jogo, um risco. A tudo isso, embora a indizibilidade da ação, chamo eu motricidade" (SERGIO, 1999, p. 24)

É, portanto, fundamental estar sensível e atento para com as intencionalidades no que diz respeito a qualidade dos modos relacionais e mais, saber interpretá-los na sua qualidade essencial de existência, ou seja, a motricidade. Com isso podemos avançar nas discussões acerca da participação do corpo-motrício nas experiências educativas. Sugerimos que nos tornemos afetados ao considerar que:

- Somos corpo e, ser corpo, tem relação com tudo que diz respeito ao sentido de ser-motrício:

É fundamental romper as barreiras dos dualismos e a supervalorização do racionalismo em direção a uma experiência educativa cuja gênese é a corporeidade humana. Um caminho, entre possíveis, é a adoção do corpo como referência para as diferenças, olhar o olhar do outro e os encontros dos modos de ser-motrício.

- A intersubjetividade materializa-se nos corpos dialógicos:

Os corpos são distintos em sua estrutura física, o corpo materializado em sua forma. $\mathrm{O}$ ato de olhar é revelador desse modo de compreender as distintas formas de ser. O olhar a que nos referimos é mais amplo em sentido do que o ato de ver. O olhar é o contato do ser com o seu entorno cujos sentidos dos órgãos sensoriais da experiência transportam-se aos sentidos próprios da linguagem humana, cuja capacidade de recriar a realidade é a essência. Se nos apropriarmos dessa natural condição humana vamos compreender que, como extensão a essa característica, os modos de interagir com o mundo, com os outros e consigo mesmo seguem o mesmo princípio das distinções visíveis no corpo manifesto. Nos corpos diferentes habitam diferentes mundos formados e diferentes sentidos de mundo. A educação deverá, portanto, deixar que os corpos mostrem sua essência para amplificar as possibilidades de existir, para que possamos vê-lo.

- Toda nossa vida é interdiscursiva:

Trata-se de uma mudança de paradigma que encontra na fenomenologia/hermenêutica uma orientação para ressignificar as relações interhumanas onde o corpo e a motricidade são essencialmente o existir no afeto.

O desafio é sair da condição de distinções comparativas classificatórias para avançar na direção das distinções dialógicas. Se estendermos essa condição para o campo da educação, em especial na condição de ser eu um afeto para outro, vamos direcionar e compreender as experiências educativas não como um processo de formatação de condutas motrícias a partir de escalas de classificação, mas um processo de estabelecimento de diálogo com os muitos mundos motrícios.

- A educação é o espaço de diálogo dos muitos mundos motrícios, é o espaço de exercício dos corpos dialógicos:

Os processos comparativos fortalecem os processos de dominação e de poder e, por ele são alimentados, formando um ciclo de desigualdades reproduzido nos espaços educativos. Na atualidade, esses componentes estão fortemente representados na esfera simbólica e na esfera da linguagem. Os grandes conflitos da trama educativa são alimentados pela busca de afirmação de seus grupos/mundos/modos-de-ser que pouco, ou quase nada, apresentam possibilidade de diálogos para a formação da alteridade. Sustenta-se a eliminação do diferente. Projeta-se o mais capaz. Destitui-se de presencialidade significativa aquele que não corresponde aos processos valorativos pré-determinados.

As orientações das principais instituições (família, igreja, escola, clube, etc) sobre as diferenças perdeu espaço de orientação para o individualismo, o que torna a 
perspectivas de compreensão do outro e das relações inter-humanas um mundo cujas possibilidades de diálogo existem na afirmação de uns sobre os outros. Queremos reforçar a questão: por que os humanos tanto necessitam desses processos comparativos/classificatórios? Será que é possível viver outros modos a inter-relação humana? Não existem outros modos de afetarmos uns aos outros?

A motricidade nós inspira a transcendência. Precisamos assumir corajosamente a ação de provocação às rupturas dos modelos restritos da experiência educativa para adentrarmos de "corpo inteiro" num modelo libertador, expressivo, afetuoso, solidário, criativo, estético, ético e sobretudo político.

\section{Sobre o cuidado e o deixar ver.}

Pensar junto afeto e educação nos coloca, como já apontamos anteriormente de algum modo, o desafio de cuidar e deixar ver. E quem nos ajuda a entender isto é a poeta Adélia Prado.

No livro Solte os Cachorros, na prosa 11 a poeta escreve:

A coisa mais triste que eu já vi é suicídio de criança, eu fico adoecida só de ter esse pensamento, os cabelos do meu corpo ficam em pé diante dessa coisa que consegue ser a mais horrorosa de todas. Eu peço a Deus, começando do tutano dos meus ossos, que livre os meninos de nós todos, sem escapar nenhum, desse tremendo horror, peço à Sagrada Família que faça a nossa casa ter uma natureza de alegria, um sentimento seguro, formado pela cantiga na boa, pela mão cosendo, cozinhando, acarinhando, sem as profundas vaidades que esvaziam o coração e nos deixam tão fracos. Obrigação nossa, de pai e de mãe, é dar amor perfeito, é falar olha fulano é assim, assim, assado, Deus existe, esta vida tem fim, estamos aqui é emprestados, a fim de fazer o bem, amar nossos semelhantes. É debater com eles quando a tiririca das más companhias e das influências ruins ameaçar a lavoura. Eu tenho pra mim, depois que a gente tem filho só existe uma tarefa pra fazer: cuidar deles. O que está mais perto do amor de pai e de mãe é ódio de pai e de mãe. Que graça tem meu boteco prosperar se faltar alegria dentro da minha casa? Segue o fio da amargura das pessoas pra ver onde ele vai parar: esbarra no pai e na mãe. (2006, p. 38)

O destaque está no sentido do cuidado. A palavra em sua origem latina refere à reflexão, à cogitação que, de algum modo remete à prevenção.

Na prosa de Adélia Prado a tarefa de pai e mãe é anunciada como este exercício de pensar e ajudar a pensar o viver, a fim de colaborar para que as crianças bem construam o seu existir ou, como diz na mesma prosa, para que elas deem "(...) conta de sofrer sem perder a esperança". (p. 39)

Eis aqui mais uma dimensão do afeto: o cuidado como expressão daquele compromisso anunciado por Paulo Freire de fazer da prática educativa uma experiência que favoreça à liberdade. Na prosa não está indicado que o cuidado determina o futuro das crianças ou que elas estarão imunes a qualquer coisa, mas que estarão em condições de enfrentarem o viver. Este cuidado, na prosa da poeta, está ligado à experiência de amar: o cuidado, portanto, como uma responsabilidade que tenho pelo outro. $\mathrm{O}$ mesmo compromisso de pai e de mãe, se aplica à experiência de 
ensinar e aprender, em que pese as distinções entre a paternidade/maternidade e a docência. É preciso se comprometer com as crianças.

Isto a poeta o diz, de modo explicitamente vinculado à prática educativa, na prosa 10 do mesmo livro.

Eu não sei o que estou fazendo aqui na sala dos professores, morrendo de sono neste horário vago que eles chamam feiamente de buraco. Não sei por que eu dou aulas. Rasamente eu sei: me sinto na obrigação de fazer qualquer coisa pelo Reino de Deus. Profundamente, se tivesse garantias de que não pecava, ia fazer o que gosto, isto é, nada. Mas um nada muito produtivo. De bruços no chão, apesar da minha idade, ia tourear formigas. (p. 33)

Dar aulas encontra seu sentido maior em fazer algo pelo Reino de Deus que, na tradição cristã, pertence às crianças.

A poeta, deste modo, na inspiração do que já tratamos sobre a fenomenologia, o querer bem e a motricidade, reitera a necessidade, para não falar em urgência, de que a vida, o cotidiano da experiência educativa seja refundado a partir deste compromisso de cuidar das crianças para que sigam com esperança. Mais do que isto, é preciso ter a coragem de deixar as crianças experimentarem o seu mundo, acompanha-las amorosamente na degustação da realidade como primeiro gesto para a instauração da prática educativa, para que esta não se transforme em lugar de desespero para as crianças, posto que insensível ao seu desejo de desvendar o mundo. É o que a poeta diz na prosa 15 do livro Solte os Cachorros.

PAI QUE ESTAIS NO CÉU e dentro do meu coração, inclinai vossos ouvidos para o meu sofrimento e tende misericórdia de mim que tenho casa de cimento e vidro e não posso dormir no campo sob um manto de estrelas. Coisa dolorosa feita de barro e poeira, o homem no seu quarto, de noite, pelejando pra escrever no papel, com lápis, nó e tropeço, a dor do seu peito. É que nada apazigua, Deus me deixa sofrer. Mesmo depois que inauguraram com meu nome o Centro de Educação Para Mães e Moças, nem a mais mínima miséria se afastou de mim. Fico querendo a Bíblia muito mais velha que já é, porque quanto mais velha, mais perto de Deus, cujo lugar é o princípio. Não tem sentido o que digo? Ninguém se assuste se eu virar assassina. Eu já sou assassina, eu desejo a morte de tudo que obriga um menino a escrever: mãe, estou desesperado. O que é que eu faço, em que língua vou fazer um comício, uma passeata que irrompa nos gabinetes, nas salas dos professores que tomam cafezinho e arrotam sua incomensurável boçalidade sobre o susto de meninos desarmados? Fazem política, os desgraçados, brigam horas e horas pela aula a mais, o tostão a mais, o enquadramento, o quinquênio, o milênio de arrogância, frustração e azedume. Deus te abençoe, filhinho, vai pra escola, seja educado e respeitador, honra teu mestre. Mestre? Onde é que tem um mestre no Brasil pra que eu lhe beije as mãos? Já não basta ser gente pra encanecer de dor? Ainda têm as escolas que se aplicar neste esmero de esvaziar dos meninos seu desejo de bois, grama e pequenos córregos? Ó ofício demoníaco de encher de areia e confusão o que ainda é puro e tenro cálice. Não quero dar aulas, ó meu Deus, me livra desta aflição, me deixa dormir, me 
deixa em paz, aula de nada, de nada, aula de religião eu não quero dar. Falo e me aflijo porque sei que não tem outro caminho senão começar de baixo, de trás, do fim da história, quando Deus pega Adão e lhe mostra as coisas, lhe deixa dar nome às coisas, lhe deixa, deixa, ruminando seu espanto, sua alegria, sua primeira palavra... O senhor presidente, ó senhor ministro, escuta: o menino foi à escola e escreveu a sua mãe: estou desesperado. Escuta quem tenha ouvidos: os meninos do Brasil fenecem entre retórica, montanhas de papel e medo. Entre ladrões, como Cristo na cruz. (p. 47-48)

Admirar-se do mundo, deixar a criança com a alegria de se encantar com o que já não é mistério para o adulto, para o docente é desafio posto para quem entendeu as inevitáveis relações entre educação e afeto.

Uma experiência educativa que se pretenda libertadora, marcada pelo sentido de ser e de mundo precisa, desde a visão da poeta - bem como dos outros lugares teóricos apresentados -, cuidar e deixar ver.

Quem, todavia, ousará, "pateticamente", afetado pelas possibilidades de sentido decorrentes da admiração corporal do mundo, pela curiosidade da criança, pensar a educação desde o corpo, o mundo e o afeto?

\section{Referências}

FREIRE, Paulo. A importância do ato de ler. São Paulo: Autores Associados: Cortez, 1989.

. Pedagogia da autonomia: saberes necessários à prática educativa. São Paulo: Paz e Terra, 1996)

HUSSERL, Edmund. A crise da humanidade europeia e a filosofia; (intro. e trad. Urbano Zilles). Porto Alegre: EDIPUCRS, 2002.

KELLER, Helen. El mundo donde vivo. Trad. Ana Becciu. Girona, Espanha: Editora Atalanta, 2012, disponível em: http://www.ignaciodarnaude.com/textos_diversos/Keller,Helen,El\%20mundo\%20don de\%20vivo.pdf. Último acesso: setembro de 2015.

LAUAND, Luis Jean, JOSGRILBERG, Rui de Souza. Estudos em Antropologia, Religião e Educação. São Paulo: Factash Editora, 2015.

MERLEAU-PONTY, Maurice. Fenomenologia da Percepção. São Paulo: Martins Fontes, 1999.

Psicologia e pedagogia da criança. São Paulo: Martins Fontes, 2006.

PIEPER, Josef. Que é Filosofar? São Paulo: Loyola, 2007.

PRADO, Adélia. Manuscritos de Felipa. São Paulo/Rio de Janeiro: Record, 2007.

Solte os Cachorros. Rio de Janeiro: Record, 2006.

SERGIO, Manuel e colaboradores. O Sentido e a ação. Lisboa: Instituto Piaget, 1999.

SÉRGIO, Manuel. Alguns olhares sobre o corpo. Lisboa: Instituto Piaget, 2003.

RICOEUR, Paul. O Si-mesmo como outro. São Paulo: Martins Fontes, 2014. 